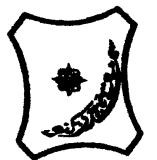

Bayero Journal of Pure and Applied Sciences, 5(1); 171 - 174

Received: October, 2011

Accepted: June, 2012

ISSN $2006-6996$

\title{
EFFECTS OF AQUEOUS WHITE GRUBS EXTRACT ON SOME MARKERS OF LIVER INJURY IN GUINEA PIGS
}

\author{
${ }^{* 1}$ Murtala, Y., ${ }^{1}$ Alhassan, A. J. ${ }^{1}$ Babandi, A. and ${ }^{2}$ Suleiman, K. \\ ${ }^{1}$ Department of Biochemistry, Bayero University, Kano, Nigeria \\ ${ }^{2}$ Department of Biological Science, College of Arts, Science and Remedial Studies, Kano, Nigeria \\ *Correspondence author: murtalakanya@yahoo.com
}

\begin{abstract}
The effects of aqueous white grubs extract on some markers of liver injury was studied in guinea pigs with $\mathrm{CCl}_{4}$-induced liver damage. Serum levels of aspartate aminotransferase (AST), alanine amino transferase (ALT), alkaline phosphatase (ALP), cholesterol and triglyceride were analysed in guinea pigs after subcutaneous administration of $100 \mathrm{mg} / \mathrm{kg} \mathrm{CCl}_{4}$ followed by oral treatment with $0.834 \mathrm{~g} / \mathrm{kg}$ of white grub extract in order to asses the curative effect of the extract against liver damage. Guinea pigs treated with $0.834 \mathrm{~g} / \mathrm{kg}$ extract for 48 hours following subcutaneous injection of $100 \mathrm{mg} / \mathrm{kgCCl}_{4}$ had serum AST, ALT and ALP levels not statistically different compared to normal control (at p>0.05) but decreased significantly compared to toxicity control ( $p>0.05)$. The serum levels of cholesterol and triglyceride in the test showed no statistical difference (at P>0.05) compared to normal control. However, comparing the test values with toxicity control shows a significant increase in both cholesterol and triglyceride levels (at P<0.05). The serum levels of AST, $A L T, A L P$, cholesterol and triglyceride when the treatment was extended to 96 hours also showed no statistical difference compared to normal control (at P>0.05). However, there was a significant decrease in serum AST, ALT and ALP while serum cholesterol and triglyceride were significantly increased compared to toxicity control (at $P<0.05)$. This result clearly indicates aqueous that white grubs' aqueous extract possess hepatoprotective property against $\mathrm{CCl}_{4}$ induced liver damaged in guinea pigs.
\end{abstract}

Keywords: Aqueous white grubs extract, Hepatoprotective, Liver damage, $\mathrm{CCl}_{4}$

\section{INTRODUCTION}

Nowadays, traditional medicine has brought to focus a wider coverage of primary healthcare delivery, not only in the African region but also, to various countries of the world (Acharya and Anshu, 2008). It is the first choice of healthcare treatment for at least $80 \%$ of Africans suffering from high fever and other common ailments (Oliver, 1959).

World Health Organisation (2008) reported that, some animal parts, in addition to medicinal plants are the major components used in traditional medicine. Traditional medicine is the sum total of all knowledge and practices, whether explicable or not, used in diagnosis, prevention and elimination of physical, mental or social imbalance and relying exclusively on practical experience and observations handed down from generation to generation, whether verbally or in writing (WHO, 2008). Nowadays, traditional medicine, as a major African socio-cultural heritage, obviously in existence for several decades, was once believed to be primitive and wrongly challenged with animosity by foreign religions and conventional or orthodox medical practitioners (Oliver, 1959). In recent years, natural products are of interest because of increase in drug resistance by disease causing organisms (WHO, 2008) and that traditional remedies are being sought by a cross section of scientist for various ailments (Chandresena, 1995).
White grubs are the larvae of May beetle also called June beetles, found in the genus phyllophaga, of which there are over 100 different species. The phyllophaga larvae and other larvae of the family scorabacidea are often referred to as "white Grubs." Phyllophaga species and other related insects are distributed through out the United States and Canada (Kendall, 2005). In Africa the species of Phyllophaga is widely distributed and was found in Nigeria, Niger Republic, Uganda etc (Alhassan et al., 2009).

The adult white grubs (May beetles) are about 12 to $25 \mathrm{~mm}$ long, they are often yellow to dark reddish brown to black, robust, oblong, shining beetles, while some are more brightly coloured. The larvae length varies from 20 to $45 \mathrm{~mm}$. The larvae are white with $C$ - shape body, brown head and three pairs of legs (Ritcher, 1966). It normally feed upon roots and decaying vegetation through the summer and, in the autumn, they migrate to depth of up to 1.5 meters in the soil and remain inactive until spring (Ritcher, 1966).

In Northern Nigeria, white grubs among Hausa Fulani is called "Gwazarma or Dole - dole" and is used in the treatment of jaundice, fever and general body weakness, and as food ingredient by various communities (Alhassan, et al., 2009). 
Liver is a multifunctional organ, largely responsible for nutrient and xenobiotics metabolism. It is the heart beat of biotransformation, altering a wide range of biochemical substances, depending on the physiological needs. It is also critical in the storage of a number of biochemical compounds such as excess iron, some vitamins and excess glucose as glycogen (Nduka, 1999).

Carbon tetrachloride $\left(\mathrm{CCl}_{4}\right)$ has been reported to induce lipid peroxidation and liver damage (Nduka, 1999) as in viral hepatitis, cirrhosis and obstructive jaundice, leading to an increase in the levels of aspartate aminotransferase (AST), alanine aminotransferase (ALT) and alkaline phosphatase (ALP) in the blood. These enzymes are mostly contained in the liver, and when parenchymal cells of the liver are damage, the enzymes leak into the blood (Zimmerman, 1976). Since the aqueous white grub extract has been reported to be used as a medicine against hepatitis, therefore, need arises to investigate its efficacy in the curing of $\mathrm{CCl}_{4}$-induced liver damage in guinea pigs. In order to assess the hepatocurative effect of white grub's aqueous extract on chemically induced liver damage, the serum AST, ALT and ALP as well as cholesterol and triglycerides levels in guinea pigs were analysed.

\section{MATERIALS AND METHODS \\ Sample Collection and Identification}

White grubs used as sample were collected by hand picking at dump site in Kanya village, Babura Local Government, Jigawa State. It was authenticated at the Department of Biological Sciences, Bayero University, Kano.

\section{Extract Preparation}

White grub $(60 \mathrm{~g})$ was weighed using digital balance and squeezed to release the extract in $500 \mathrm{~cm}^{3}$ of distilled water. The white grub residue (squeezed white grubs) was allowed to stand for five hours to avoid excessive moisture and then reweighed. The difference between the intact white grub and the white grub residue was obtained. The difference in weight gives the amount of white grubs extract dissolved (extracted) in the distilled water to form an aqueous solution. The volume of the solution was adjusted so as to make a solution of $0.05 \mathrm{~g} / \mathrm{cm}^{3}$. The dose of extract given to the animals was $0.834 \mathrm{~g} / \mathrm{kg}$ twice per day at ten hours interval for fourty eight and ninety six hours respectively.

\section{Experimental Animals}

The animals used in this work were guinea pigs (weighing 400-500g) obtained from the Animal House of the Department of Pharmacology and Clinical Pharmacy, Ahmadu Bello University, Zaria. They were then housed in animal house, Department of Biological Sciences, Bayero University, Kano and allowed to acclimatise for two weeks and fed with their normal starter feed and water.

\section{Treatment}

Thirty (30) guinea pigs were used for the study. The animals were divided into three (3) groups: Group I contains six (6) guinea pigs which serve as normal control; liver damage was not induced and extract was also not administered. Group II contains twelve (12) guinea pigs serving as toxicity control; the liver damage was induced but the extract was not administered. Group III contains also twelve (12) animals, in which liver damage has been induced, followed by administration of the extract. Group III animals were further subdivided into two groups each containing six (6) animals of which one sub - group was given extract for $48 \mathrm{hrs}$ and the other sub group for 96 hours. The extract was administered orally while $100 \mathrm{mg} / \mathrm{kg} \mathrm{CCl}_{4}$ was administered subcutaneously. High doses of $\mathrm{CCl}_{4}(90-120 \mathrm{mg} / \mathrm{Kg})$ can induce massive liver damage and may persist for longer period, giving rise to ideal hepatotoxicity rats model (Alhassan, 2009). The animals were sacrificed after 48 hours and 96 hours respectively. Blood samples were collected and serum samples were collected for analysis.

\section{Methods}

The serum aspartate amino transferase (AST) and alanine amino transferase (ALT) activities were determined using the method of Reitman and Frankel (1957), serum ALP activity was determined by method of Kind and King (1954) while serum cholesterol and triglycerides were determined according to the procedures of Zlatkis et al., (1977) and Baginski and Zak (1960) respectively. Student $t$ - test was used to compare the activities of enzymes as well as serum cholesterol and triglyceride in the test, normal control and toxicity control.

\section{RESULTS}

Table 1 showed the mean and standard deviation for AST, ALT and ALP activities in normal control, toxicity control and guinea pigs treated with $\mathrm{CCl}_{4}$ followed by aqueous white grubs extract for 48 and 96 hours respectively. Serum levels of cholesterol and triglyceride in control subjects, toxicity control and guinea pigs with liver damage, followed by treatment with extract for 48 and 96 hours respectively were shown in Table 2. The enzyme activities, cholesterol and triglyceride values for normal control and toxicity control for both 48 and 96 hours were significantly different (at $p<0.05$ ), while the values of guinea pigs treated with extract and those of normal control were not significantly different $(p>0.05)$. 
Bajopas Volume 5 Number 1 June, 2012

Table 1: Serum AST, ALT and ALP activities in Guinea pigs treated with $100 \mathrm{mg} / \mathrm{Kg} \mathrm{CCl}_{4}$ followed by $0.83 \mathrm{~g} / \mathrm{kg}$ aqueous white grubs extract for 48 and 96 hours.

\begin{tabular}{|c|c|c|c|c|}
\hline Group & Treatment & $\begin{array}{l}\text { AST } \\
(U / L)\end{array}$ & $\begin{array}{l}\text { ALT } \\
(U / L)\end{array}$ & $\begin{array}{l}\text { ALP } \\
\text { (KA) }\end{array}$ \\
\hline Group I & (normal control) & $10.00 \pm 1.74^{\mathrm{a}, \mathrm{c}}$ & $9.33 \pm 1.17^{a, c}$ & $9.00 \pm 1.73^{a, c}$ \\
\hline Group IIa & (toxicity control for 48 hours) & $* 90.00 \pm 2.00^{\mathrm{a}, \mathrm{b}}$ & $70.00 \pm 0.00^{a . b}$ & $40.50 \pm 0.00^{\mathrm{a}, \mathrm{b}}$ \\
\hline Group IIIa & $\left(\mathrm{CCl}_{4}\right.$ and extract for 48 hours ) & $13.33 \pm 1.00^{b}$ & $12.46 \pm 1.02^{b}$ & $12.00 \pm 1.05^{\mathrm{b}}$ \\
\hline Group IIb & (toxicity control for 96 hours) & $* 67.00 \pm 2.00^{\mathrm{a}, \mathrm{c} . \mathrm{d}}$ & $52.00 \pm 0.00^{\mathrm{a}, \mathrm{c}, \mathrm{d}}$ & $30.10 \pm 1.50^{\mathrm{a}, \mathrm{c}, \mathrm{d}}$ \\
\hline Group IIIb & ( $\mathrm{CCl}_{4}$ and extract for 96 hours) & $12.05 \pm 1.02^{c, d}$ & $10.21 \pm 1.15^{\mathrm{c}, \mathrm{d}}$ & $10.0 \pm 1.75^{c, d}$ \\
\hline \multicolumn{5}{|c|}{$\begin{array}{l}\text { Values are mean } \pm \text { standard deviation, similar superscripts in the same column are statistically different at } \\
\mathrm{P}<0.05 . \mathrm{n}=6 \\
\text { Asterisk }(*) \text { Indicates administration of } \mathrm{CCl}_{4} \text { for up to } 4 \text { days ( } 96 \text { hours) had serum liver enzymes lower than that } \\
\text { of } 2 \text { days ( } 48 \text { hours). }\end{array}$} \\
\hline
\end{tabular}

Table 2: Serum cholesterol and triglycerides in Guinea pigs treated with $100 \mathrm{mg} / \mathrm{Kg} \mathrm{ccl}_{4}$ followed by $0.834 \mathrm{~g} / \mathrm{kg}$ aqueous white grubs extract for 48 and 96 hours

\begin{tabular}{|c|c|c|c|}
\hline Group & Treatment & Cholesterol (mmol/L) & Triglyceride (mg\%) \\
\hline Group I & (normal control) & $3.60 \pm 0.06^{\mathrm{a}, \mathrm{c}}$ & $140.67 \pm 4.04^{\mathrm{a}, \mathrm{c}}$ \\
\hline Group IIa & (toxicity control for 48 hours ) & $0.74 \pm 0.00^{a, b}$ & $70.00 \pm 0.00^{a, b}$ \\
\hline Group IIIa & ( $\mathrm{CCl}_{4}$ and extract for 48 hours) & $2.64 \pm 1.05^{b}$ & $130.62 \pm 5.77^{b}$ \\
\hline Group IIb & (toxicity control for 96 hours) & $1.00 \pm 0.00^{\mathrm{a}, \mathrm{c}, \mathrm{d}}$ & $85.00 \pm 2.05^{a, c, d}$ \\
\hline Group IIIb & ( $\mathrm{CCl}_{4}$ and extract for 96 hours) & $3.50 \pm 0.14^{\mathrm{c}, \mathrm{d}}$ & $130.67 \pm 10.00^{c, d}$ \\
\hline
\end{tabular}

\section{DISCUSSION}

The result of this work showed that, the normal control guinea pigs had serum AST, ALT, ALP, cholesterol and triglyceride levels (Tables 1 and 2) to be within the normal ranges of up to $12 \mathrm{U} / \mathrm{L}$ for serum AST and ALT (Rietman and Frankel, 1957), 5 - $10 \mathrm{~K} \mathrm{~A}$ units for serum ALP (Kind and King, 1954), 3.9 $5.75 \mathrm{mmol} / \mathrm{L}$ for serum cholesterol (Zlatkis et al., 1977) as well as 135 - $159 \mathrm{mg} \%$ for serum triglyceride (Baginski and Zak, 1960) respectively.

Guinea pigs with $\mathrm{CCl}_{4}$ induced liver damage but no treatment (toxicity control) had serum AST, ALT and ALP levels significantly higher compared to those of normal controls (at $\mathrm{P}<0.05$ ) as depicted on Table 1 . This result is in line with work reported by Nduka (1999) and Alhassan et al., (2009) that $\mathrm{CCl}_{4}$ is toxic chemical which inflicts acute necrosis upon liver causing clinical conditions like infective hepatitis. However, guinea pigs treated with $0.834 \mathrm{~g} / \mathrm{kg}$ aqueous white grubs extract for 48 and 96 hours had serum AST, ALT and ALP very close to those of normal control but significantly decreased (at $\mathrm{P}>0.05$ ) as compared to toxicity control (Table 1). This would probably be due hepatocurative effect of aqueous white grubs extract on chemically induced hepatocellular damage. Although the mechanism of this dramatic lowering effect is not clearly understood, it could however, be due to extract-enhanced rapid regeneration of hepatocytes.

The serum levels of cholesterol and triglyceride in toxicity control were significantly decreased (at $\mathrm{P}>0.05$ ) as compared to normal controls. This decrease in serum cholesterol as well as triglyceride levels in toxicity control (after inducing liver damage for 48 and 96 hours) may be associated with hepatic damage. This observation agrees with the findings reported previously by Eisenberg et al., (1973) that, hepatic enzyme systems are responsible for cholesterol and fatty acid synthesis and also the formation of triacylglyceride, phosphoglycerides and lipoproteins taking place in the liver. Therefore, hepatic injury may probably be associated with decrease in cholesterol synthesis. Nevertheless, the serum cholesterol and triglyceride levels in guinea pigs after 48 and 96 hours of treatment with aqueous white grubs extract showed a significant increase in serum cholesterol and triglyceride compared to toxicity control (at $\mathrm{p}<0.05$ ). The decrease in the serum levels of AST, ALT and ALP of tests compared to toxicity control and the increase in serum cholesterol and triglyceride are indications of possible curative effect of aqueous white grubs extract on $\mathrm{CCl}_{4}$ induced liver damage. 


\section{Conclusion}

The result of this work therefore, has supported the use of aqueous white grub extract in folk medicine

\section{REFERENCES}

Alhassan, A.J., Sule, M.S., Aliyu, S.A., and Aliyu, M.D. (2009). Ideal Hepatotoxicity Model in Rats using $\mathrm{CCl}_{4}$. Bayero Journal of Pure and Applied Sciences, 2 (2): 185 - 187.

Acharya, D. and Anshu, S. (2008). Indigenous Herbal Medicines: Tribal Formulations and Traditional Herbal Practices Aavishkar Publishers, Jaipur. Pp. $45-60$

Baginski, E.S., and Zak, B (1960): Clinical Chemistry Acta. 5: 834

Chandresena, J.P.C. (1995). The Chemistry and Pharmacology of Ceylon and Indian Medicinal Plants. (Ceylon): H and C Press, Sri lanka. P.163

Eisenberg, S., Bilheimer, D.W., Levy, R.I. and Lindgren F.T. (1973): On the metabolic Conversion of Human Plasma Very Low Density Lipoprotein to Low Density Lipoprotein. Biochemica Biophysica Acts. 326: $361-377$.

Kendall, D. (2005). Insect Taxonomy - Agroecology Biometrics - Expert Witness. Adaptations and Dynamics; Fuxter Verlag, Stuttgart, P. 551.

Kind, P.R.N. and King, E.J. (1954): Journal of Clinical Pathology. 7: 322 against liver disease. Thus its continued usage traditionally as remedy for liver disease is recommended.

Nduka, N. (1999). Clinical Biochemistry for Students of Pathology. Longman Nigeria Plc. Lagos. 236P.

Oliver, A. (1959). Medicinal Plant in Nigeria. College of Arts, Science and Technology, Ibadan. New York University Press Pp. 11-14

Reitman, S. and Frankel, S. (1957). A Colorimetric Method for the Determination of Serum Glutamic Oxaloacetate and Glutamic Pyruvic Transaminases American. Journal of Clinical Pathalogy.

Ritcher P.O. (1966). White Grubs and their Allies: A Study of North American Scarabacoid Larvae Anegonstate Menogr Studies. Entomology. 4:1 1-219.

World Health Organisation (2008). Traditional medicine Fact sheet no. 134.

Zimmerman, H.J., (1976). Various Form of Chemically Induced Liver Injury and their Detection by Diagnostic Procedures. Environmental Health Perspectives. 15: 3- 12.

Zlatkis, A., Zak, B., and Boyle, A.J. (1977). A New Method for Direct Determination of Serum Cholesterol. Journal of Laboratory and Clinical Medicine. 41: 486 - 92. 